\title{
BhCG as a Rupture Marker in Ectopic Pregnancy: A Retrospective Study
}

\author{
Ektopik Gebelikte Rüptür Belirteci Olarak BhCG: Retrospektif Bir \\ Çalışma
}

\author{
(D) Özlem Karabay Akgül, (D) Evrim Ebru Kovalak, (D) Toygun Çakmak, (D Hakan Gürarslan
}

University of Health Sciences Turkey, İstanbul Bağcllar Training and Research Hospital, Clinic of Gynecology and Obstetrics, İstanbul, Turkey

\section{Abstract}

Objective: To find effective criteria in determining the risk of ectopic pregnancy rupture in patients with ectopic pregnancy.

Method: The data of 101 patients who were hospitalized with the diagnosis of ectopic pregnancy in the tertiary center between January 2018 and January 2021 were analyzed retrospectively. Demographic data of the patients, the month of admission, the patients' beta-human corionic gonadotropin (BhCG) values at the time of admission, blood type, endometrial thickness measured with transvaginal ultrasound, presence of adnexal mass suggestive of ectopic pregnancy and treatments applied to the patients were recorded. These data were compared between patients who had surgery for ectopic pregnancy rupture and those whose treatment was completed without it.

Results: In the statistical analysis of the data, ectopic pregnancy rupture was found significantly more frequent for a threshold value of BhCG $>4000 \mathrm{IU} / \mathrm{L}$. Other data were not statistically significant.

Conclusion: In cases of ectopic pregnancy, if the BhCG value at the time of admission exceeds the threshold value, the possibility of surgical approach increases. Medical treatment may be more successful at lower BhCG levels.

Keywords: BHcg, ectopic pregnancy, rupture prediction, tubal rupture

\section{Öz}

Amaç: Ektopik gebelik saptanmış hastalarda rüptür riskinin belirlenmesinde etkili kriterleri bulmaktır.

Yöntem: Ocak 2018-Ocak 2021 tarihleri arasında üçüncü basamak merkezde ektopik gebelik tanısı ile yatırılan 101 hastanın verileri retrospektif olarak incelendi. Hastaların demografik verileri, başvuru ayı, hastanın başvuru anındaki BhCG değeri, kan grubu, transvaginal ultrasonografi ile endometrial kalınlık, ektopik gebelik odağı varlığı ve hastalara uygulanan tedaviler kaydedildi. Bu veriler, ektopik gebelik rüptürü nedeniyle ameliyat olan ve ameliyat olmadan tedavisi tamamlanan hastalar arasında karşılaştırıldı.

Bulgular: Verilerin istatistiksel analizinde BhCG >4000 IU/L için sadece rüptür grubunda anlamlı olarak daha sık bulundu. Diğer veriler istatistiksel olarak anlamlı değildi.

Sonuç: Ektopik gebelik olgularında giriş anındaki BhCG değeri eşik değerini aşarsa ameliyat olma olasılığı artar. Düşük BhCG düzeylerinde tıbbi tedavi daha başarıı olabilir.

Anahtar kelimeler: BHcg, ektopik gebelik, rüptür öngörüsü, tubal rüptür

\section{Introduction}

Ectopic pregnancy is the pregnancy outside the uterine cavity and accounts for $1-2 \%$ of all pregnancies (1). It is an important emergency disease of the reproductive age, which can show a fatal course. The mortality rate of ectopic pregnancies ranges around $3-4 \%$ (2).
Today, pregnancies are being detected in very early weeks with sensitive pregnancy tests, high-resolution ultrasonography, Doppler ultrasonography, and magnetic resonance imaging (MRI) when necessary $(3,4)$.

Methotrexate (Mtx) treatment was first applied in ectopic pregnancy cases by Stovall et al. (5). According to current

Address for Correspondence: Özlem Karabay Akgül, University of Health Sciences Turkey, İstanbul Bağcılar Training and Research Hospital, Clinic of Gynecology and Obstetrics, İstanbul, Turkey

E-mail: ozlem74akgul@hotmail.com ORCID: orcid.org/0000-0003-0313-1893 Received: 23.06.2021 Accepted: 17.11.2021

Cite this article as: Karabay Akgül Ö, Kovalak EE, Çakmak T, Gürarslan H. BhCG as a Rupture Marker in Ectopic Pregnancy: A Retrospective Study. Bagcilar Med Bull 2021;6(4):426-430

๑C Copyright 2021 by the Health Sciences University Turkey, Bagcilar Training and Research Hospital Bagcilar Medical Bulletin published by Galenos Publishing House. 
data, approximately one third of ectopic pregnancy cases are suitable for medical treatment (6).

While the primary treatment protocol was laparoscopic salpingostomy in unruptured tubal ectopic pregnancies until 1997, medical treatment started to be accepted as a reliable treatment method with the randomized controlled study of Hajenius et al. (7).

There are many studies in the literature to find the most appropriate treatment method for ectopic pregnancies. In this study, we wanted to set approaches that might reduce the risk of ectopic pregnancy ruptures and therefore the mortality and morbidity rates of the cases by using the clinical features, examination findings and laboratory values of the patients, and contribute to the literature by determining a threshold BhCG value.

\section{Materials and Methods}

In this retrospective study, following the permission of the Non-Interventional Clinical Research and Ethics Committee of İstanbul Medipol University, dated 20.05.2021 and numbered 483,101 patients with inpatient follow-up and diagnosis of ectopic pregnancy in a tertiary health center in İstanbul for a period of 3 years between January 2018 and January 2021 were included. We used the algorithm created by Stovall and Ling (8) in 1993 for the diagnosis of ectopic pregnancy.

The month of admission, age, gravida, parity, blood type, history of previous pelvic surgery, and menstrual cycle of the last 6 months were recorded. Endometrial thickness measured with transvaginal ultrasound, BhCG value (d0BhCG) at the time of admission, presence of an adnexal mass suggestive of ectopic pregnancy, and size of the adnexal mass if present were recorded in all patients.

In cases when urgent surgical approach was not required, patients with BhCG value $>1000 \mathrm{IU} / \mathrm{L}$ received medical treatment while patients with BhCG value $<1000 \mathrm{IU} / \mathrm{L}$ were followed with expectant management. Mtx (singlemultidose) was administered intramuscularly to the patients as medical treatment. Mtx was calculated as $50 \mathrm{mg} /$ $\mathrm{m}^{2}$ and BhCG value was measured on the $4^{\text {th }}$ and $7^{\text {th }}$ days when given as a single dose. Accepting that $15 \%$ decrease in serum BhCG value between the $4^{\text {th }}$ and $7^{\text {th }}$ days is a very good indicator of the possible success of Mtx, a second dose of Mtx was administered to the patients whose BhCG values did not decrease adequately (9). Surgery was not applied unless an acute abdomen developed. Laparoscopic salpingectomy was performed in patients requiring surgical intervention.
Before starting Mtx treatment, liver function tests, complete blood count, renal function tests, and blood group determination were performed in order to determine the general health status of the patients and to understand whether there were contraindications for Mtx treatment. Patients with breastfeeding, intrauterine pregnancy, acute peptic ulcer, impaired immune system, unclear diagnosis, active pulmonary disease, renal disease, and unexplained blood disorder and patients who were not hospitalized or able to be followed up during the treatment period were excluded from the study group.

BhCG values were recorded from 101 patients at the time of hospitalization, and the patients were divided into two groups as patients who did not require surgery (medical treatment or expectant management) and patients who underwent surgery. The patients who underwent surgery were called the primary surgery group if no medical treatment was applied priorly. The patients who were operated due to the development of acute abdomen while taking Mtx or during spontaneous follow-up were called the secondary surgery group. The pathological material of the operated patients was preserved for pathological analysis and postoperative BhCG values were not followed up in the patients who underwent surgery.

The BhCG value was studied in the hospital laboratory using the Beckman counter UniCel DxI 800 immunoassay system device with the total chemiluminescent immunoassay method and the results were recorded as IU/L.

\section{Statistical Analysis}

With the Pearson chi-square test and Fisher's Exact test, statistically significant variables were evaluated between patients having and not having surgery. The threshold value for predicting rupture was determined for the d0BHcg value by ROC analysis.

\section{Results}

Of all the patients in the study group, $60.4 \%$ of the patients did not undergo surgery while $39.6 \%$ of them required surgical intervention. Of the 39 patients who underwent surgery, 28 of them $(71.80 \%)$ were operated without receiving medical treatment (primary surgery group) and 11 of them $(28.20 \%)$ were operated while having Mtx treatment (secondary surgery group).

In the distribution of patients according to the month of admission, the highest number of patients who underwent surgery was admitted in September (18.8\%) and the lowest number of patients who underwent surgery was admitted in May and August (2.0\%). 
Among the patients who underwent surgery, patients with blood groups of $\mathrm{A} \mathrm{rH}+(35.6 \%)$ and $0 \mathrm{rH}+(25.7 \%)$ were seen most frequently. Patients with blood group of $\mathrm{AB} \mathrm{rH}-$ were rarest among the patients who required surgery $(1.0 \%)$.

We did not find a significant difference in age between the groups with and without ectopic pregnancy rupture during the ectopic pregnancy treatment course.

Of 101 patients who were hospitalized for ectopic pregnancy, 16 (15.84\%) were nulliparous and 85 (84.16\%) were multiparous. We found that the risk was higher in patients with lower gravida who needed surgery. Four nulliparous patients (25\%) and 36 multiparous patients (42.4\%) needed surgical intervention. However, gravida was not a statistically significant factor in terms of operation necessity.

We observed adnexal mass suggestive of ectopic pregnancy by transvaginal ultrasound in 61 patients $(60.40 \%)$ and 25 of them (41.0\%) needed surgical intervention. In 40 patients, (39.60\%) transvaginal ultrasonography of adnexa was normal and 15 of them (37.5\%) needed surgical approach. In our study, we could not find any statistically significant difference between the patients with and without an adnexal mass suggestive of ectopic pregnancy with regard to the necessity of surgery.

In their first examination with transvaginal ultrasound, $15(31.9 \%)$ of 47 patients with an endometrial thickness measurement less than $7 \mathrm{~mm}, 15$ (45.5\%) of 33 patients with an endometrial thickness of 7-12 mm and 10 (47.6\%) of 21 patients with endometrial thickness greater than $12 \mathrm{~mm}$ were operated. We did not find any significant relevance between endometrial thickness and the necessity of surgery.

A single dose of Mtx was given to 51 (72.86\%) of 70 patients who received medical treatment, and multidose of Mtx was given to 19 (27.14\%) of them. Eight patients (15.69\%) who received a single dose of Mtx and 3 patients (15.78\%) who received multidose of Mtx were operated. Statistically, we could not find any significant difference between patients using single dose and multidose Mtx in terms of operation frequency.

Of the 70 patients who received Mtx, 11 of them $(15.70 \%)$ were operated.

One of the 3 patients who was followed with expectant management required surgery. This patient's BhCG value was $454 \mathrm{IU} / \mathrm{L}$ (Figure 1).

In the ROC analysis, predictive BhCG value was determined as $4177 \mathrm{IU} / \mathrm{L}$ in terms of surgical approach (sensitivity:

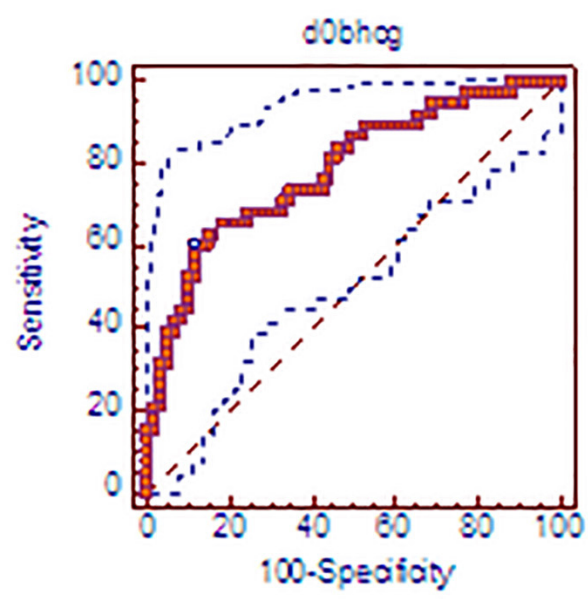

Figure 1. ROC analysis table: According to d0 BhCG, in the classification made according to the threshold value as a result of the ROC analysis, the rate of those who needed surgery was significantly higher than the threshold value.

ROC: Receiver operating characteristic

$60 \%$, specificity: $88.52 \%$, positive predictive value: 76.7 , negative predictive value: 78.3 ). AUC was 0.786 , and the data were considered reliable. According to the binarylogistic analysis based on the aforementioned threshold BhCG value of $4.177 \mathrm{IU} / \mathrm{L}$, it was found that requirement of surgical intervention was 4.8 times (OR) more likely $(\mathrm{p}<0.001)$. When all the variables are included in the model, and in the same binary logistic regression model, when we take the need for surgery as the dependent variable and the threshold value of BhCG exceeds, it is OR $=4.8(\mathrm{p}<0.001)$ times more likely that surgery is required. The d0BhCG value is higher in those requiring surgery.

\section{Discussion}

Ectopic pregnancy is an urgent gynecological condition, which may have catastrophic consequences and is seen in women of reproductive age. Ectopic pregnancies are located in fallopian tubes in $95 \%$ of cases. Rupture of the ectopic pregnancy, tubal abortion or spontaneous regression may occur in tubal ectopic pregnancies. 10$15 \%$ of maternal deaths are due to complications related to ectopic pregnancy (10). In the literature, the rate of ectopic pregnancy rupture is $32 \%$ in ectopic pregnancy patients, and it is the main cause of ectopic pregnancy-related mortality (11). Therefore, surgery is essential in ruptured ectopic pregnancy. The surgical method may be salpingectomy or salpingostomy. Criteria such as the patient's desire for fertility, the patient's general condition and hemodynamic changes may be effective in determining the surgical 
method. The surgery can be executed with laparotomic or laparoscopic approach. Mtx is used for medical treatment. Mtx treatment scheme for medical treatment is based on a 2007 study (9).

In this study, we could not find any definitive criterion to predict ectopic pregnancy rupture. We only found that patients with a BhCG value of $4177 \mathrm{IU} / \mathrm{L}$ had an increased risk of rupture. There was no statistically significant relevance between operation requirement and patients' age, endometrial thickness, gravida, presence of an adnexal mass suggestive of ectopic pregnancy, blood type, and the month of admission.

Although BhCG shows the presence of pregnancy in the patients, an adnexal mass suggestive of ectopic pregnancy may not be detected by ultrasonography. In this case, considering the possible intrauterine pregnancy and the side effects of Mtx treatment, 48-72 hours of expectant management may be considered in the hemodynamically stable patient. If BhCG value is $<2000 \mathrm{IU} / \mathrm{L}$ or the BhCG value decreases spontaneously, expectant management is suitabl (12). In our study, there were 3 patients who were eligible for expectant management. Among them, a patient with BhCG value of $454 \mathrm{IU} / \mathrm{L}$ was operated because of the development of acute abdomen and hemodynamic instability.

Although it was published in 2009 by Col-Madendag et al. (13) that endometrial thickness was a significant evaluation criterion when BhCG level was below $1000 \mathrm{IU} / \mathrm{L}$, it was not explained how many millimeters were statistically significant. According to the publication in 2009 by Knafel et al. (14), endometrial thickness is not significant in the prediction of tubal ectopic pregnancy rupture. In our study, endometrial thickness, blood type, and admission month of the patient did not have any differential effect between patients with and without ectopic pregnancy rupture.

In the literature, there are studies that are conflicted with each other in terms of the predictive value of BhCG for ectopic pregnancy ruptures. Despite previous publications showing that BhCG level is not significant in predicting the risk of rupture, a population-based study by Job-Spira et al. (15) reported that ectopic pregnancy rupture was 3 times more common in cases with $\beta$-hCG $\geq 10,000 \mathrm{IU} / \mathrm{L}$. Latchaw et al. (16) calculated BhCG threshold value $5000 \mathrm{IU} / \mathrm{L}$ in 2005. Fukami et al. (17) determined a threshold value of 3000 IU/L in 2016. While BhCG threshold value was calculated $5000 \mathrm{IU} / \mathrm{mL}$ in some publications, it was determined as $10000 \mathrm{IU} / \mathrm{L}$ in some others (18-20). In our study, we found that the need of surgical approach increased 4.8 times (OR) over the threshold value of BhCG 4177 IU/L $(\mathrm{p}<0.001)$.

The lack of patients followed by expectant management, who could have been considered as another control group, limited our study in terms of observing the course of untreated follow-up. One of three patients on expectant management had acute abdomen and salpingectomy was performed.

Patient complaints, laboratory tests and examination findings cannot fully predict ectopic pregnancy rupture and despite all advances, ectopic pregnancy rupture is still a significant cause of maternal death. Although the risk of rupture decreases by $2.5 \%$ each passing day after the first 48 hours of diagnosis, the presence of symptoms always poses risk for ectopic pregnancy rupture (11). Mtx treatment is $89 \%$ successful in the early period in ectopic pregnancy cases (20). It is known that the lower the BhCG value upon the diagnosis of ectopic pregnancy, the more successful the medical treatment can be.

\section{Conclusion}

It cannot be guaranteed that ectopic pregnancy rupture will not occur in any case, and we could not find any predictive parameter for ectopic pregnancy rupture other than BhCG in our study. Therefore, close follow-up and studies with larger patient series are required.

\section{Ethics}

Ethics Committee Approval: In this retrospective study, following the permission of the Non-Interventional Clinical Research and Ethics Committee of İstanbul Medipol University, dated 20.05.2021 and numbered 483,101.

Informed Consent: Consent was obtained from all patients.

Peer-review: Externally peer-reviewed.

\section{Authorship Contributions}

Concept: Ö.K.A., E.E.K., Design: Ö.K.A., E.E.K., Data Collection or Processing: Ö.K.A., T.Ç., Analysis or Interpretation: Ö.K.A., H.G., Drafting Manuscript: Ö.K.A., E.E.K., T.Ç., Critical Revision of Manuscript: H.G., Ö.K.A., Final Approval and Accountability: Ö.K.A., H.G., E.E.K., T.Ç.

Conflict of Interest: No conflict of interest was declared by the authors.

Financial Disclosure: The authors declared that this study received no financial support. 


\section{References}

1. Hajenius PJ, Mol F, Mol BW, Bossuyt PM, Ankum WM, van der Veen F. Interventions for tubal ectopic pregnancy. Cochrane Database Syst Rev 2007;2007(1):CD000324.

2. Berg CJ, Callaghan WM, Syverson C, Henderson Z. Pregnancyrelated mortality in the United States, 1998 to 2005. Obstet Gynecol 2010;116(6):1302-1309.

3. Mol BW, Hajenius PJ, Engelsbel S, Ankum WM, Van der Veen F, Hemrika DJ, et al. Serum human chorionic gonadotropin measurement in the diagnosis of ectopic pregnancy when transvaginal sonography is inconclusive. Fertil Steril 1998;70(5):972-981.

4. Condous G, Okaro E, Khalid A, Lu C, Van Huffel S, Timmerman $\mathrm{D}$, et al. The accuracy of transvaginal ultrasonography for the diagnosis of ectopic pregnancy prior to surgery. Hum Reprod 2005;20(5):1404-1409.

5. Stovall TG, Ling FW, Buster JE. Outpatient chemotherapy of unruptured ectopic pregnancy. Fertil Steril 1989;51(3):435-438.

6. Sivalingam VN, Duncan WC, Kirk E, Shephard LA, Horne AW. Diagnosis and management of ectopic pregnancy. J Fam Plann Reprod Health Care 2011;37(4):231-240.

7. Hajenius PJ, Engelsbel S, Mol BW, Van der Veen F, Ankun WM, Bossuyt PM, et al. Randomized trials of systemic methotrexate versus laparoscopic salpingostomy in tubal pregnancy. Lancet 1997;350(9080):774-779.

8. Stovall Tg, Ling FW. Diagnostic and therapeutic algorithms minimizing surgical intervention. J Reprod Med 1993;38(10):807812.

9. Kirk E, Condous G, Van Calster B, Haider Z, Van Huffel S, Timmerman D, et al. A validation of the most commonly used protocol to predict the success of single-dose methotrexate in the treatment of ectopic pregnancy. Hum Reprod 2007;22(3):858-863.

10. Sara HG, Uzelac PS. Early pregnancy risks. In Current diagnosis and treatment obstetrics and gynecology, DeCherney AH, Nathan L, Goodwin MT, Laufer N (editors). 10th ed. Columbus, OH: McGrawHill, 2007:259-272.
11. Bickell NA, Bodian C, Anderson RM, Kase N. Time and the risk of ruptured tubal pregnancy. Obstet Gynecol 2004;104(4):789-794.

12. Korhonen J, Stenman UH, Ylöstalo P. Serum human chorionic gonadotropin dynamics during spontaneous resolution of ectopic pregnancy. Fertil Steril 1994;61(4):632-636.

13. Col-Madendag I, Madendag Y, Kanat-Pektas M, Danisman N. Can sonographic endometrial pattern be an early indicator for tubal ectopic pregnancy and related tubal rupture? Arch Gynecol Obstet 2010;281(2):189-194.

14. Knafel A, Basta P, Skotniczny K, Paweł M, Krzysztof B, Rokita W, et al. Pekniecie ciazy ektopowej-czy mozemy zapobiec tej komplikacji? [Ectopic pregnancy rupture-can it be prevented?]. Ginekol Pol 2009;80(10):734-739. (Polish)

15. Job-Spira N, Fernandez H, Bouyer J, Pouly JL, Germain E, Coste J. Ruptured tubal ectopic pregnancy: risk factors and reproductive outcome: results of a population-based study in France. Am J Obstet Gynecol 1999;180(4):938-944.

16. Latchaw G, Takacs P, Gaitan L, Geren S, Burzawa J. Risk factors associated with the rupture of tubal ectopic pregnancy. Gynecol Obstet Invest 2005;60(3):177-180.

17. Fukami T, Tsujioka H, Matsuoka S, Sorano S, TohyamaA, Yamamoto $\mathrm{H}$, et al. Rupture risk factors of fallopian tubal pregnancy Clin Exp Obstet Gynecol. 2016;43(6):800-802.

18. Goksedef BPC, Kef S, Akca A, Bayik RNE, Cetin A. Risk factors for rupture in tubal ectopic pregnancy: definition of the clinical findings. Eur J Obstet Gynecol Reprod Biol 2011;154(1):96-99.

19. Ackerman R, Deutsch S, Krunholz B. Levels of human chorionic gonadotropin in unruptured and ruptured ectopic pregnancy. Obstet Gynecol 1982;60(1):13-14.

20. Barnhart KT, Gosman G, Ashby R, Sammel M. The medical management of ectopic pregnancy: a meta-analysis comparing "single dose" and "multidose" regimens. Obstet Gynecol 2003;101(4):778-784. 